\title{
Ethnobotanical, Phytchemical, and Allelopathic Potentinal of Traditional Medicinal Plants
}

\author{
Ishwari Gyawali ${ }^{1,2, a, *}$, Sachin Bhattarai ${ }^{1,3, b}$, Subodh Khanal ${ }^{1, c}$ \\ ${ }^{1}$ Institue of Agriculture and Animal Sciences, Tribhuvan University, Nepal \\ ${ }^{2}$ South China Agricultural University, Guangzhou, China \\ ${ }^{3}$ University of Natural resources and Life Sciences, Vienna, Austria \\ *Corresponding author
}

\section{A R T I C L I N F O A B S T R A C T}

Research Article

The study aims to report the ethnobotanical significance of medicinal plants for the treatment of various diseases, phytochemical constituents of those plants, their allelopathic effect, and impact of those plants on the socioeconomic aspect in Gulmi and Okhaldhunga district of Nepal. Altogether 41 species of medicinal plants from two areas were documented, using a semi-structured

Received : 09/09/2020

Accepted : 14/10/2020 questionnaire. They have been using those species for the treatment of different ailment ranging from gastrointestinal problems, respiratory tract related problems, cuts and wounds, and dermatological problems. 18 of the potentially valuable medicinal plants were brought for performing secondary metabolites tests in methanol extract. The extracts have shown the presence of alkaloid, carbohydrate, glycosides, flavonoids, tannins, terpenoids, saponins, oil and protein, out

Keywords:

Medicinal plants Ethnobotany

Secondary metabolites Phytotoxicity

Socioeconomics of which alkaloid was found to be present in every sample. In contrast, only 5 possessed protein. Out of 18 plant extracts, 11 most valued ones were isolated to carry out allelopathy tests on mungbean seed. Only the control treatment bored germination of the mungbean with full radicle and plumule development. This study also reports the impact of the use of medicinal plants in people's daily life.

\section{Introduction}

Nepal is one of the most diversified countries in the world. Biodiversity is a hub that makes Nepal unique and different from the rest of others. The different physiographic zones due to attitudinal variation have resulted in vegetation ranging from the subtropical to alpine. A developing country like Nepal addresses its corresponding health needs by utilizing several medicinal plants available in their respective areas. They are readily available at affordable prices and possess no side effects so that it is the only source of medicine for the poor people (Acharya and Acharya, 2009). The study done in 2019 shows that more than 6000 species of flowering plants and about 530 ferns are found in Nepal (Tiwari et al., 2019). The Medicinal and Aromatic Plant Database of Nepal (MAPDON) has enlisted 1624 medicinal and aromatic plants that are commonly available in the market under both cultivation and wild forms (Sharma et al., 2004).
Medicinal plants synthesize and accumulate some bioactive compounds and secondary metabolites like alkaloids, sterols, terpenes, flavonoids, saponins, tannin and can be used for the synthesis of various antimicrobial and antifungal drugs, which have some physiological effect in the body (Kalimuthu er al., 2010). Medicines made from them are safe, less expensive, more efficient and rarely have side effects (Vaghasiya et al., 2011). Phytomedicine is derived from seeds, flowers, fruits, roots, and bark of plants (Cragg and Newman, 2001). The number of phytochemicals belonging to different classes of chemicals has shown inhibitory effects on all types of microorganisms in the in-vitro condition (Cowan, 1999). Lack of advanced labs and screening centers to examine them, to refine them, and to know the actual application of these valuable gold isn't available in every corner of the country, so they have to be rushed into the main cities for the simple activities. 
The phenomenon of one plant having a direct or indirect effect (harmful or beneficial) on another plant by producing a chemical compound is allelopathy (Lehoczky et al., 2011). Seeds, flowers, fruits, and leaves of living or decomposing plant material produce chemicals called allelochemicals and used as weed control without any negative impact on the main crops (Weston, 1996). Allelopathy and its effect would be a lot useful to farmers in several cases, which include residual allelopathy, allelopathic attributes in soil health improvements, disease management, weed management, and microbial allelopathy (Amb and Ahluwalia, 2016). Due to a lack of extension and encouraging actions from the experts, farmers of the research sites do not have any idea.

A Germination test is done to view the germination potential and capacity, the viability of the seed in a controlled or natural environment. Mungbean (Vigna radiata $\mathrm{L}$. Wilczek) is a short duration leguminous crop that is grown in rainy and spring seasons both (DB et al., 2014). More than $75 \%$ of mungbean is cultivated in the Eastern and Central Terai region where irrigation facility is available, while the remaining $25 \%$ is produced in the Western Terai and foothills of Nepal (Shrestha et al., 2011). This study reports the impact of the use of medicinal plants in people's daily life. Also, it justifies that the extraction of secondary metabolites can be significantly used for synthesizing bioactive drugs, including biopesticide, as they have an allelopathic effect.

\section{Methodology}

\section{Selection of Site}

Field Survey was conducted in the Ruru Rural Municipality and Likhu Rural Municipality of Gulmi and Okhaldhunga district of Nepal respectively (Figure1). Ruru Rural Municipality is located in Gulmi district of Province No.5 of Nepal. The site has a latitude of $28^{\circ} 4^{\prime} 0^{\prime \prime} \mathrm{N}$ and longitude of $83^{\circ} 15^{\prime} 0^{\prime \prime} \mathrm{E}$, located at an elevation 650-1650 $\mathrm{m}$ above sea level. The climate of Ruru ranges from warm temperate to subtropical with a temperature ranging from $8^{\circ} \mathrm{C}$ to $28^{\circ} \mathrm{C}$. The area of this municipality is $67.38 \mathrm{~km}^{2}$, with a population of 18,581 , according to Ministry of Federal Affairs and Local Development of Ruru, Census of Nepal 2011.

Likhu is a rural municipality located in Okhaldhunga District of Province No. 1 of Nepal. It is situated at $27.3132^{\circ} \mathrm{N}$ latitude and longitude of $86.299^{\circ} \mathrm{E}$ with an elevation of $1500 \mathrm{~m}$ above sea level. The Subtropical climate is found with a mean annual temperature of $15.5^{\circ} \mathrm{C}$ in this area. Ministry of Federal Affairs and Local Development has stated that Likhu has an area of 88.03 $\mathrm{km}^{2}$ with a population of 14049 as the Census of Nepal 2011. These places are located in the eastern and western, mid-hill region and occupy many medicinal plant consumers.

\section{Data Collection}

A household survey was carried out by preparing a semi-structured questionnaire for respondents who were selected by purposive sampling method and altogether 70 samples; 35 households from each locality were selected. The survey was conducted to collect the information related to medicinal plants, major parts used and purpose of use, impact on their daily lives, and the use of those plants by the young generation. Similarly, a key informant survey was carried out with a local healer to identify the plants brought from the sites.
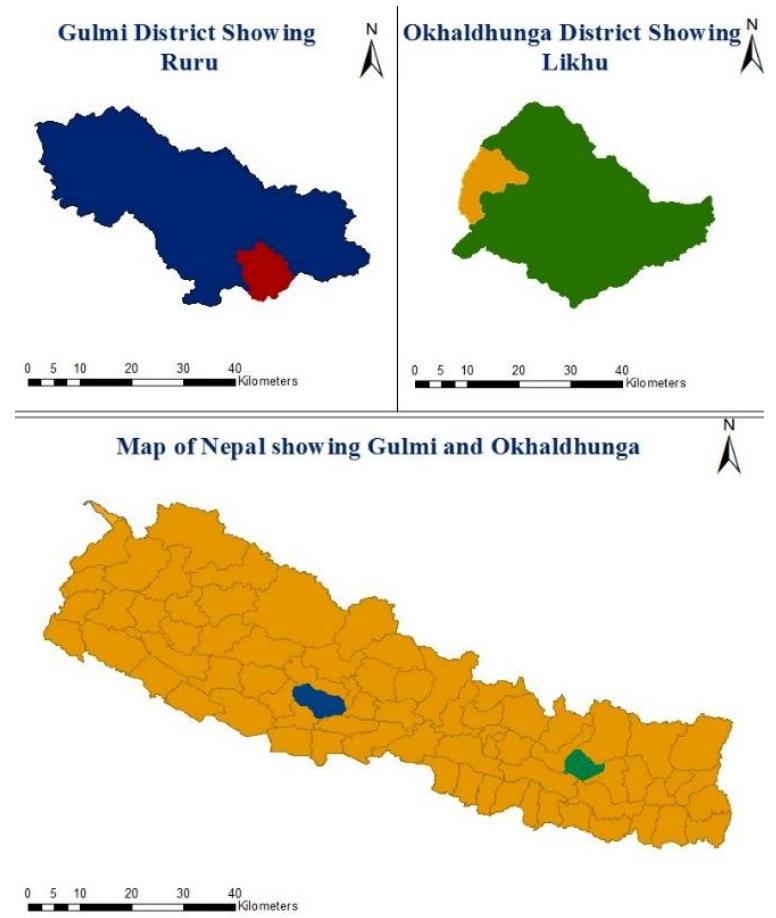

Figure1. Map showing the study sites

\section{Collection and Preparation of Plant Material}

During field research, altogether 41 medicinal plants used in daily lives were collected for taxonomic identification. Plants were collected from the local forest and cultivated site of the area, i.e., Damlachaur and Shringeshwor (Lekha) forest of Ruru and Chautara Paatal forest of Likhu. Department of plant resource Kathmandu confirmed the plants. Among the collected plants, 18 majorly used plants were separated for phytochemical screening. Most used plant parts were separated thoroughly, cleaned with running tap water followed by distilled water, and thoroughly dried in the shade at room temperature to lower their moisture. The dried parts were grinded into a fine powder and were stored in airtight bottles.

\section{Extract Preparation}

About 10-15 g of powder of each plant sample was soaked in $100 \mathrm{ml}$ of methanol for $72 \mathrm{hrs}$ with frequent agitation, so that soluble matter is well dissolved (Ncube et al., 2008). Filtration was done, and each extract was evaporated at $50^{\circ} \mathrm{C}$ in the oven to get a paste form which was stored at room temperature. For further studies, additional methanol was added in the paste obtained earlier.

\section{Qualitative Phytochemical Test}

Preliminary qualitative phytochemical screening of those samples was carried by following standard protocols.

Test for Alkaloids

The methanolic extract of the crude dry powder was treated with an equal amount of Wagner's reagent and a few drops of Mayer's reagent. The cream precipitate and 
reddish-brown/brown precipitate in Wagner's reagent and Mayer's reagent respectively indicated the presence of alkaloid (Lellau and Liebezeit, 2001).

\section{Test for Carbohydrate}

Methanolic extract, when added to Molisch's reagent, violet colour ring, and when Fehling's solution was added to the extract, deep violet colour at the junction of two layers indicated the presence of carbohydrates (Auwal et al., 2014).

\section{Test for Glycosides}

$1 \mathrm{ml}$ of extract was allowed to react with $1 \mathrm{ml}$ of concentrated Sulphuric acid; the formation of reddish colour when allowed to stand for 2 minutes validated the presence of glycoside (Lokman et al., 2013).

\section{Test for Flavonoids}

$2 \mathrm{ml}$ of extract was taken in a test tube, and few drops of liquor ammonia were added to it. Addition of concentrated sulphuric acid to the obtained solution gave a yellow colour with a cracking sound(Ayoola et al., 2008).

\section{Test for Phenol}

Ferric Chloride Test: In the $2 \mathrm{ml}$ of methanolic extract, $3 \mathrm{ml}$ of $5 \% \mathrm{w} / \mathrm{v}$ ferric chloride solution was added. The appearance of a blue-black colour indicated the presence of tannins and phenols(Lellau and Liebezeit, 2001).

Test for Terpenoids

Salkowaski Test: 5 drops of concentrated sulphuric acid were added in $2 \mathrm{ml}$ of extract, shaken, and allowed to stand. The appearance of the greenish-blue colour indicated the presence of terpenoids (Lokman et al., 2013)

\section{Test for Saponins}

Olive Oil Test: $5 \mathrm{ml}$ of extract was added to a few drops of olive oil. The appearance of froth indicated the presence of saponins (Gul et al., 2017).

\section{Test for Oils}

Filter paper Test: Few drops of the extract was pressed between two filter papers and kept undisturbed. After 12 hours, the oil stain on the paper confirmed the presence of oil and fat (Marka et al., 2013).

\section{Test for Protein}

Biuret Test: To $2 \mathrm{ml}$ of extract, $1 \mathrm{ml}$ of $5 \% \mathrm{w} / \mathrm{v}$ sodium hydroxide and $1 \mathrm{ml}$ of $1 \% \mathrm{w} / \mathrm{v}$ copper sulphate were added. The change of colour in the solution to Violet/pink/purple indicated the presence of proteins (Narasimhan, 2014).

\section{Allelopathic Effect on Germination}

The phytotoxic activity of different plant extracts on the selected plant was investigated by using methanol extracts.

\section{Extraction}

Out of the total extracts, only 11 extracts were selected based on their higher chemical constituents (phytochemical test) to observe both allelopathy as well as germination test. Already prepared and stored paste (2.4) was used for this test. $50 \mathrm{ml}$ of distilled water was added to the paste and was kept for 24 hours at room temperature. Then, each solution was filtered to remove debris. Each stock solution was kept in the refrigerator until use (Devkota and Sharma, 2015).

\section{Seed Culture}

Mungbean seeds (Vigna radiata) of locally grown variety were collected from the agronomy lab of IAAS Paklihawa. The mungbean seed lot was selected because the current season was the sowing period of this crop, and it was assumed that it would perform better with the prepared extract solution in the laboratory. Seed culture was carried out as similar to earlier study (Aasifa et al., 2014). Seeds were surface sterilized with bleach water to avoid contamination and were thoroughly rinsed several times with sterile water. For testing, 36 Petri dishes were washed, dried, and then sterilized in an autoclave at $60^{\circ} \mathrm{C}$ for 24 hours. Altogether, 11 treatments and one control with distilled water and 3 replications were arranged in the environmental science and agroecology lab of Paklihawa Campus in a completely randomized design (CRD) format. Filter papers were kept in each Petri dish, and twenty seeds were placed in separate Petri dishes at equal distances. Irrigation was provided daily by the extract and water for 15 days. All the experimental Petri dishes were kept at room temperature for 15 days. Germination percentage on a given period and time for germination compared to control was noted. The treatments were as follows:

\section{$\mathrm{T}_{1}$ - Water (Control)}

$\mathrm{T}_{2}$ - Chiraito- Swertia chirayita (Roxb. Buch. Ham ex C. B. Clarke)

$\mathrm{T}_{3}$ - Bojho- Acorus calamus (L.)

$\mathrm{T}_{4}$ - Asuro- Justicia adhatoda (L.)

$\mathrm{T}_{5}$ - Pudina- Mentha spicata (L.)

$\mathrm{T}_{6}$ - Barro- Terminalia bellirica Gaertin.) (Roxb.)

$\mathrm{T}_{7}$ - Harro- Terminalia chebula (Retz.)

$\mathrm{T}_{8}$ - Titepati- Artemisisa vulgaris (L.)

$\mathrm{T}_{9}$ - Sugandha- Valeriana jatamansi (Jones.)

$\mathrm{T}_{10}$ - Kalo Niuro- Tectaria macrodonta (L.)

$\mathrm{T}_{11}$ - Thulo Okhat- Astilbe rivularis (Ham. ex D. Don)

$\mathrm{T}_{12-}$ Paiyun- Prunus cerasoides (Buch. Ham ex D. Don)

\section{Statistics}

Statistical analyses were performed using GraphPad Prism 7.0 software (Chicago, IL, USA). Methods of statistical analyses were chosen based on the design of experiment and are indicated in the figure legends. $\mathrm{P} \leq 0.05$ was considered to be statistically significance.

\section{Result}

In this, the study medicinal plants majorly used by the people of Gulmi and Okhaldhunga are listed according to the respondent's responses which are available in the mentioned area. List of medicinal plants with their local name, scientific name, family, parts used and uses are presented in table (Table 1, Table 2, and Table 3) which is arranged according to the location and alphabetical order. Such type of study was done earlier in Resunga of Gulmi district (Acharya, 2012), Palpa district (Ale et al., 2009).

The phytochemical analysis of the medicinal plants collected from Ruru (Acorus calamus, Cheilanthes bicolor, Emblica officinalis, Justicia adhatoda, Mentha spicata, Occimun sanctum, Terminalia bellirica Terminalia chebula and Zanthoxylum armatum) and Likhu (Amaranthus viridis L., Artemisia vulgaris, Astilbe rivularis, Chenopodium album, Hyoscyamus niger, Prunus cerasoides, Swertia chirayita, Tectaria macrodonta L., Valeriana jatamansi L.) are given in Table 4. From the study, alkaloid was found in all plants tested. Acorus calamus showed a positive response to all the phytochemical tested (Mamta and Jyoti, 2012). 
Table 1. Showing the major medicinal plants used by both Ruru and Likhu

\begin{tabular}{|c|c|c|}
\hline S.N & Botal & Family \\
\hline 1. & $\begin{array}{lc}\text { Acorus calamus } \mathrm{L} . & \text { Bojho } \\
\text { Uses: } \text { Used as anti-spasmodic, carminative, } & \text { used for sore thro }\end{array}$ & $\begin{array}{l}\text { Acoraceae } \\
\text { and voice disorders, anthelm }\end{array}$ \\
\hline 2. & $\begin{array}{ll}\text { Aloe vera }(\mathrm{L} .) \text { Burm. f. } & \text { Ghyu kumari } \\
\text { Uses: Heal burning wounds, regulate pressure, gel is used in the }\end{array}$ & $\begin{array}{l}\text { Xanthorrhoeaceae Leaves } \\
\text { rm of cream to soothe, heal and moist }\end{array}$ \\
\hline 3. & $\begin{array}{l}\text { Amaranthus viridis } \mathrm{L} . \\
\text { Uses: Fever, pain, asthma, diabetes, dysentery, urinary disorc }\end{array}$ & $\begin{array}{l}\text { Amaranthaceae } \\
\mathrm{s} \text {, liver disorders anc }\end{array}$ \\
\hline 4. & $\begin{array}{l}\text { Artemisia vulgaris } \\
\text { Uses: } \text { Stomach-ache, Skin diseases, cut wounds, itching, dela } \\
\text { rheumatism, bronchitis, fever, headache, and as a remedy fo } \\
\text { diseases and foul ulcers as an alternative; applied to the head o }\end{array}$ & $\begin{array}{l}\text { Asteraceae Entire plant } \\
\text { ed or irregular menstruation, anorexia, gastritis, } \\
\text { diarrhoea. Used in fomentations given in skin } \\
\text { young children for the prevention of convulsion }\end{array}$ \\
\hline 5. & $\begin{array}{l}\text { Centella asiatica } \mathrm{L} \text {. } \\
\text { Uses: Skin diseases, indigestion, toothache problems, and st }\end{array}$ & $\begin{array}{l}\text { Apiaceae Enti } \\
\text { problem, purify blood, and in }\end{array}$ \\
\hline 6. & $\begin{array}{lc}\text { Ocimum sanctum } \mathrm{L} . & \text { Tulsi } \\
\text { Uses: Gastric disorder, urino-genital system disorder, throa }\end{array}$ & Lamiaceae \\
\hline 7. & $\begin{array}{l}\text { Prunus cerasoides Buch. Ham ex D. Don Paiyun } \\
\text { Uses: Seed oil is used for stone diseases, twigs and leaves ar }\end{array}$ & $\begin{array}{l}\text { Rosaceae } \\
\text { aid to be abortive, } \mathrm{t}\end{array}$ \\
\hline 8. & $\begin{array}{l}\text { Swertia chirayita Roxb. Buch. Ham ex C. B } \\
\text { Uses: Fever and headache }\end{array}$ & Gentianaceae \\
\hline
\end{tabular}

Table 2. Showing the major medicinal plants used by Likhu

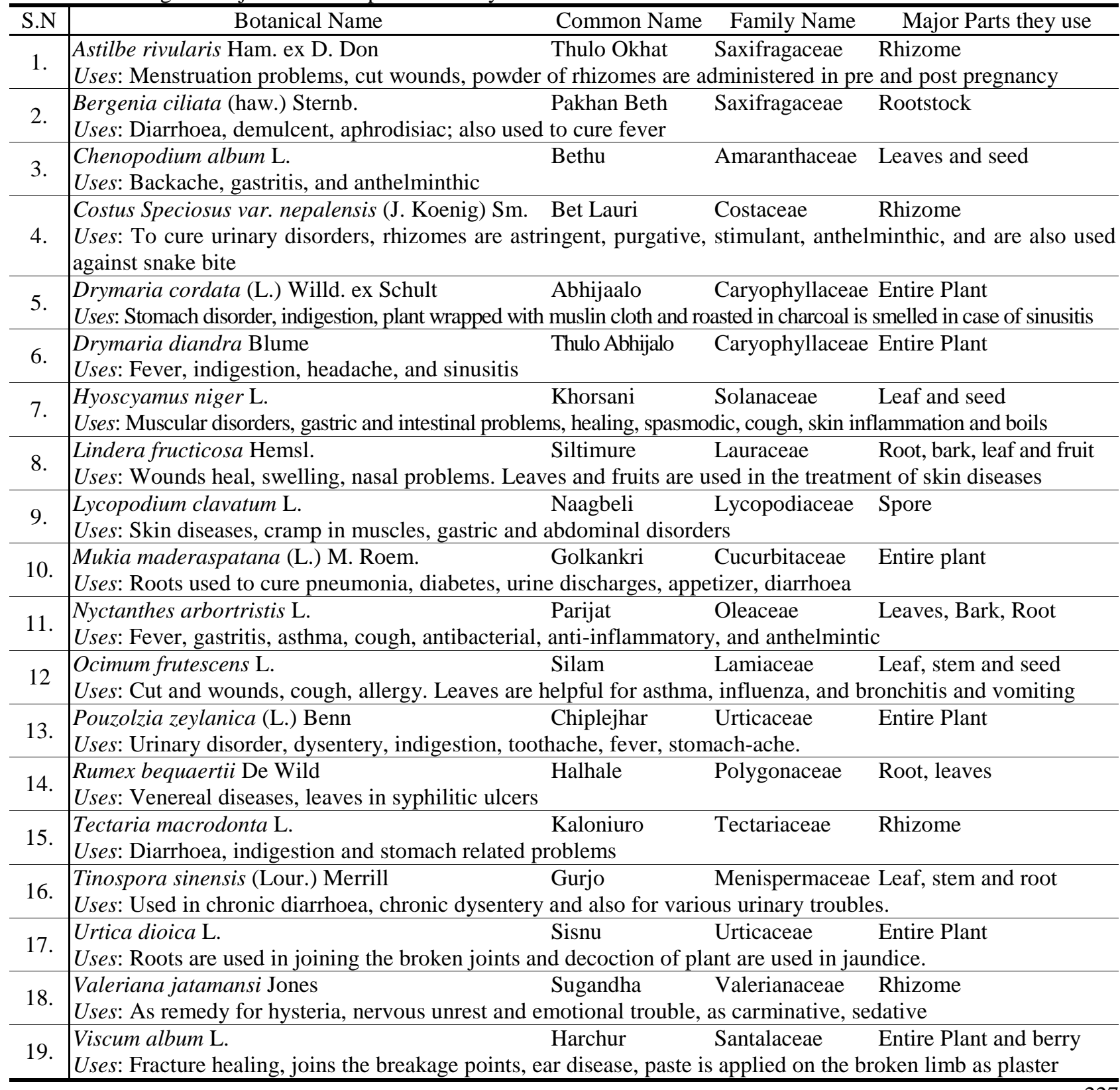


Table 3. Showing the major medicinal plants used by Ruru

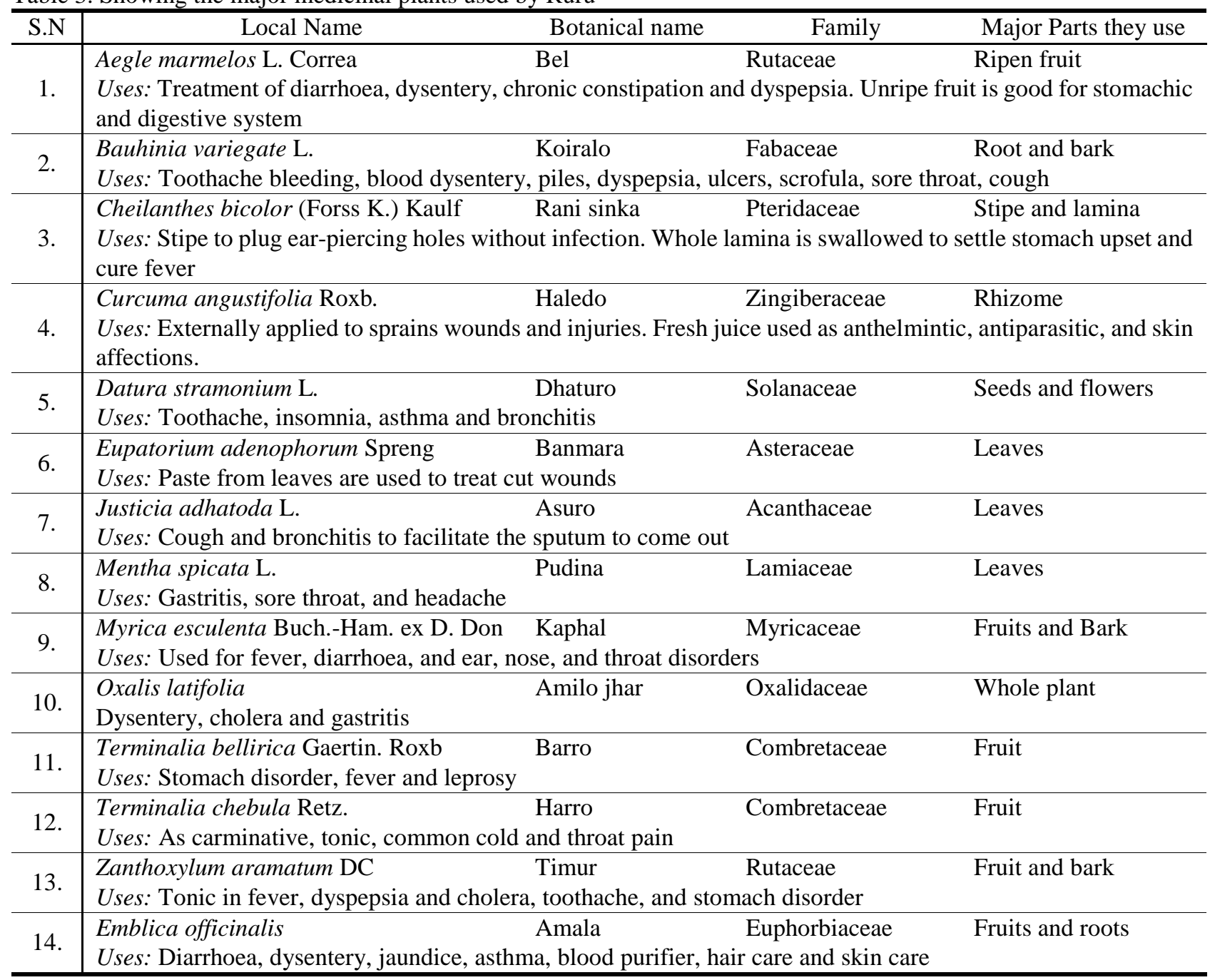

Table 4. Phytochemical Analysis of Medicinal Plants

\begin{tabular}{|c|c|c|c|c|c|c|c|c|c|c|}
\hline \multirow{2}{*}{ Name of plants } & \multirow{2}{*}{ Parts used } & \multicolumn{9}{|c|}{ Secondary Metabolites } \\
\hline & & $\mathrm{Al}$ & $\mathrm{Ca}$ & $\mathrm{Gl}$ & $\mathrm{Fl}$ & $\mathrm{Ta}$ & $\mathrm{Te}$ & $\mathrm{Sa}$ & Oi & $\operatorname{Pr}$ \\
\hline Acorus calamus & Rhizome & + & + & + & + & + & + & + & + & + \\
\hline Amaranthus blitum syn lividus & seed & + & - & - & + & + & + & + & - & + \\
\hline Artemisia vulgaris & Leaves & + & - & + & + & + & - & + & + & - \\
\hline Astilbe rivularis & Bark & + & + & - & + & - & + & + & + & + \\
\hline Cheilanthes bicolor & Whole Plant & + & + & + & + & + & - & + & + & - \\
\hline Chenopodium album & Leaves, stem & + & + & - & - & + & + & + & - & - \\
\hline Emblica officinalis & Fruit & + & + & + & + & + & - & + & + & - \\
\hline Hyoscyamus niger & Leaves & + & + & - & + & + & - & - & + & - \\
\hline Juslica adhatoda & Leaves & + & - & - & + & + & + & - & + & - \\
\hline Mentha spicata & Leaves & + & + & + & - & + & + & + & + & - \\
\hline Occimun sanctum & Leaves and Seed & + & + & - & + & + & + & - & - & - \\
\hline Prunus cerasoides & Bark & + & + & + & - & + & + & + & + & + \\
\hline Swertia chirayita & Stem & + & - & - & + & + & + & + & + & - \\
\hline Tectaria macrodonta & Rhizome & + & + & + & + & + & - & + & + & - \\
\hline Terminalia bellirica & Fruit & + & + & + & + & + & + & - & + & - \\
\hline Terminalia chebula & Fruit & + & + & - & + & + & + & - & + & - \\
\hline Valeriana jatamansi & Rhizome & + & + & + & + & - & + & - & + & + \\
\hline Zanthoxylum aramatum & Seeds & + & + & + & + & + & + & - & + & - \\
\hline
\end{tabular}

Al: Alkaloids, Ca: Carbohydrates, Gl: Glycosides, Fl: Flavonoids, Ta: Tannins, Te: Terpenoids, Sa: Saponins, Oi: Oils, Pr: Protein, + indicate presence, - indicate absence 


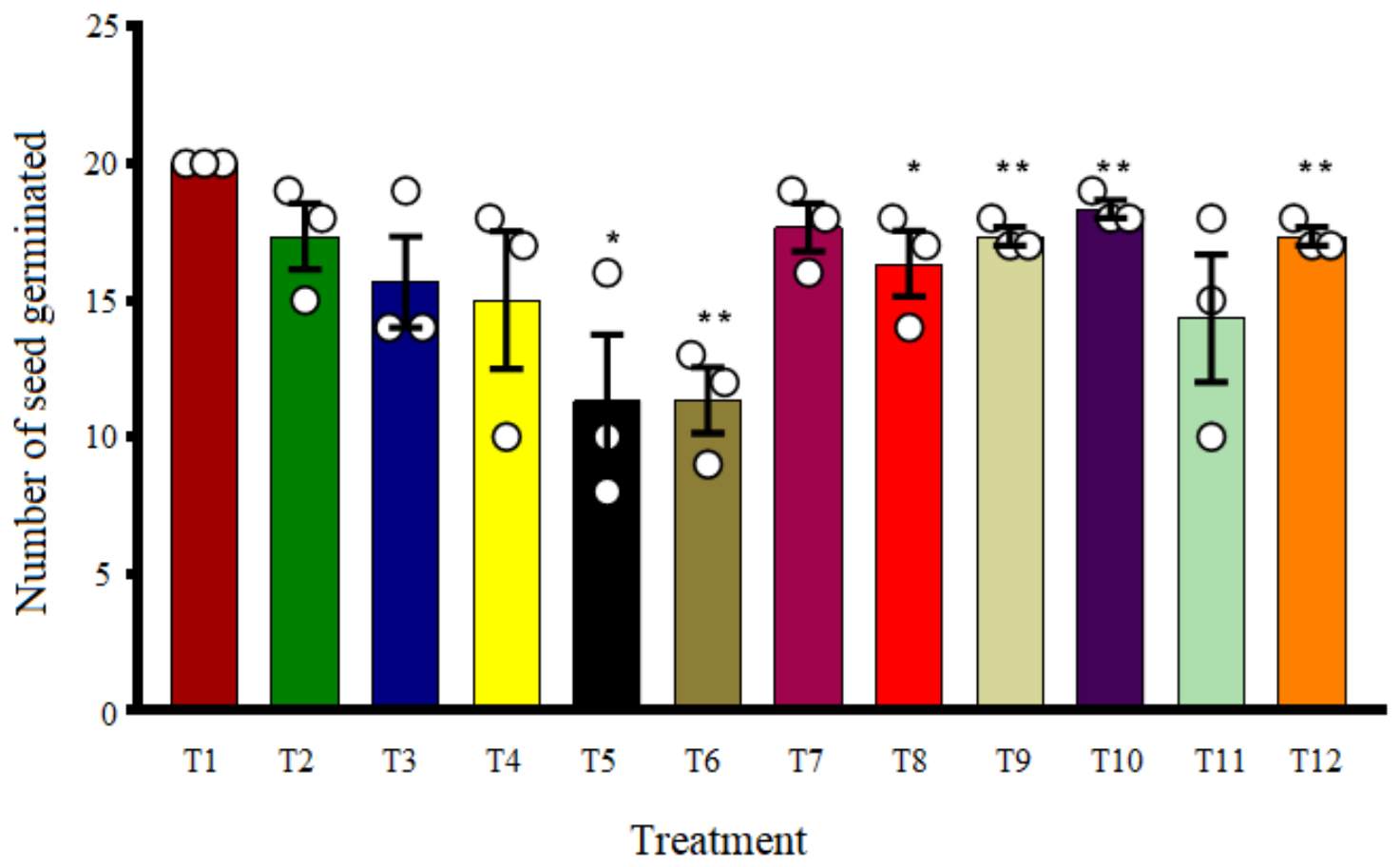

Figure 2. Average number of seeds germinated in each treatment

Results are presented as mean $\pm \mathrm{SEM},{ }^{*} \mathrm{P} \leq 0.05, * * \mathrm{P} \leq 0.01$ (Control versus Treatment) and by non-paired $\mathrm{t}$ test.

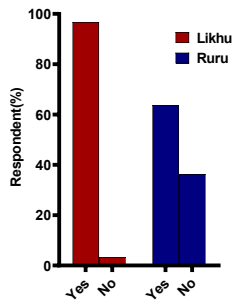

a

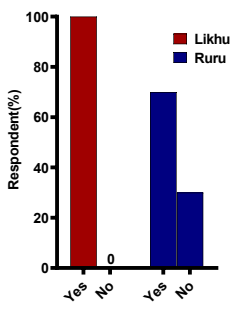

e

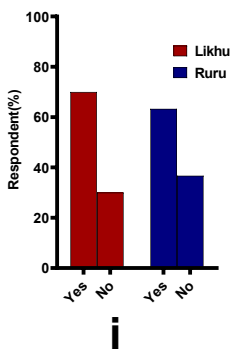

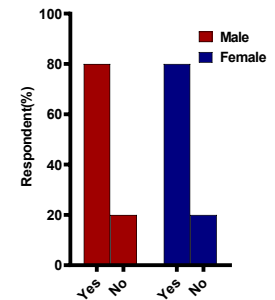

b

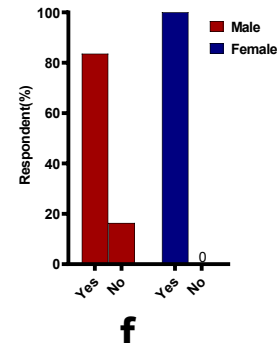

f

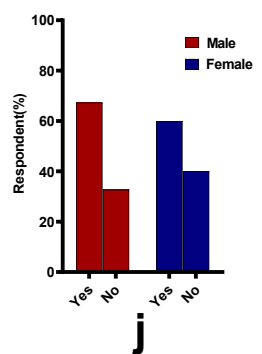

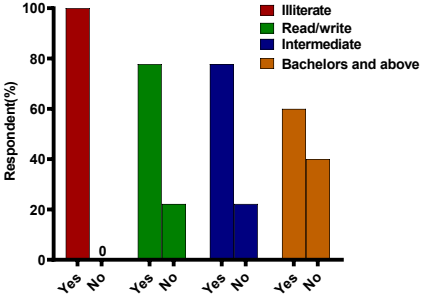

C

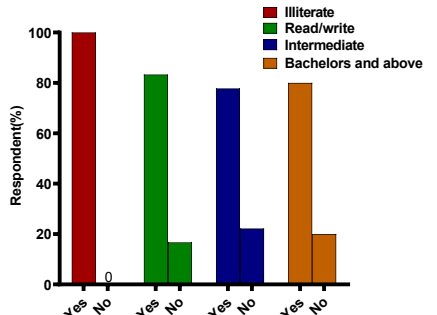

g

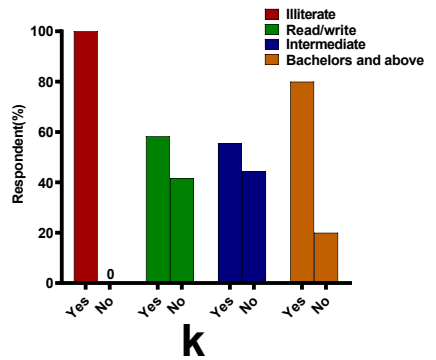

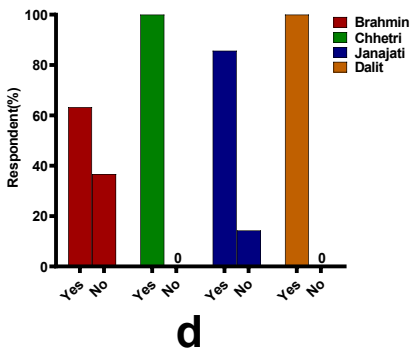
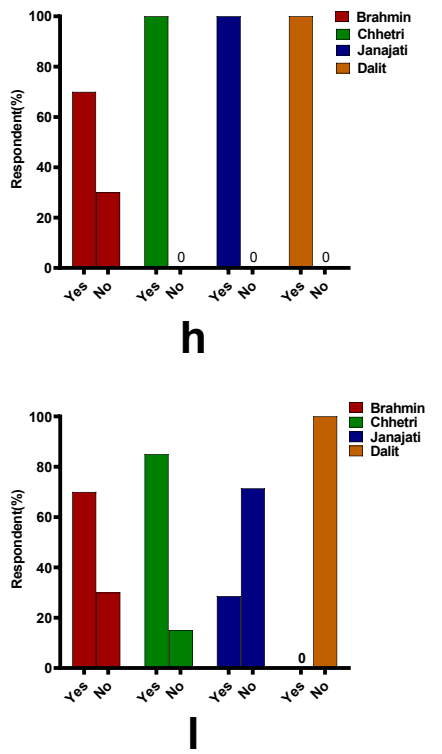

Figure 3. Socioeconomic Attributes about medicinal plants

(a-d) Use of medicinal plants over synthesized medicines: a. Village* $(\chi 2=10.417, \mathrm{df}=1)$, b. gender c. Education d. Ethnicity (e-h) Effect of medicinal plants in their daily lives: e. Village* $(\chi 2=10.59, \mathrm{df}=1)$ f. gender g. Education h. Ethnicity* $(\chi 2=10.588, \mathrm{df}=3)$ (i-j) Young family members acquainted with the medicinal plants i. Village j. gender k. Education 1. Ethnicity** $(\chi 2=13.746, \mathrm{df}=3)$ Data information: * indicate $\mathrm{P} \leq 0.05$ and ** indicate $\mathrm{P} \leq 0.01$ by chi square test 
The Methanol extract of Amaranthus viridis L. showed the presence of alkaloids, tannins, protein, flavonoid, and saponin (Nehal et al., 2016) and the absence of carbohydrate, glycoside, and oils (Gavit and Patel, 2019).

Flavonoid was found to be absent in Mentha spicata (Kakatiet al., 2016) and Prunus cerasoides (Thakur and Sidhu, 2014). Glycoside, carbohydrate, saponin and protein was found to be absent in methanol extract Justicia adhatoda which is also found in research conducted in (Malathi, 2018) but a study done by (Abhishek et al., 2014) showed that glycoside was present. Phytochemical analysis Astilbe rivularis shown that glycosides and tannin were absent, which is supported by (Shrestha et al., 2015). Hyoscyamus niger showed the absence of glycosides, terpenoids, and saponin, but a study done by (Krishnaveni and Hariharan, 2017) showed that glycoside and saponin were present. Phytochemical analysis of fruits of Emblica officinalis and Terminalia bellirica showed that alkaloids, flavonoid, tannins, phenols, and saponin were present but protein was absent (Badon et al., 2016). Our study showed that glycoside and carbohydrates were also present in both of them. Glycosides and saponin were not detected in the fruits of Terminalia chebula (Vemuri et al., 2019) while another study by (Krishnaveni M et al., 2017) showed that glycoside is present including other as alkaloids, saponin, and oils. Saponin and protein were absent in Zanthoxylum armatum (Mehta et al., 2013). Main phytoconstituents such as tannins, carbohydrates, phenols, and alkaloids were found to be present while protein and flavonoid were absent in the methanolic leaf extracts of Chenopodium album, results are under the former studies (Kaur et al., 2018; Saini et al., 2019). The results of phytochemical analysis of Swertia chirayita showed the presence of various phytochemicals such as alkaloids, flavonoid, phenols, saponin, tannins and terpenoids (Kumar et al., 2015). Phytochemical study of Occimun sanctum discovered presence of alkaloids, flavonoid and tannins while it showed negative result in case of protein, saponin and oil (Panchal and Parvez, 2019). Phytochemical analysis of methanol extracts of Tectaria macrodonta revealed the presence of saponin, tannin, flavonoid, phenol, carbohydrate and glycosides (Poudyali and Singh, 2019). The qualitative phytochemical screening of the of Prunus cerasoides leaves showed the presence of alkaloids, terpenoids, phenol, tannins, saponin, glycosides, carbohydrate, protein in methanol extract (Joseph et al., 2016).

We also observed the allelopathic effect of the medicinal extracts inhibiting the growth of some mungbean seeds, i.e. not $100 \%$ of the seeds in all three replications were germinated except in control. The data are graphically shown in Figure 1.

Among these twelve treatments, only treatment 1, i.e., controlled, resulted in full germination of the mungbean seed, along with the radicle and plumule development. In contrast, the remaining resulted in germination but inhibited the further growth to radicle and plumule in given time. The first germination was seen in 3 days, and within 7 days all were germinated in control. While in other extracts, the germination started only after 8 days and continued up to 15 days, but no further growth was seen. There was a significant difference between control and other treatments (Figure 2). Socio-economic attributes to medicinal plants with respect to the village, gender, education, ethnicity, and different aspect is shown in Figure 3. The responses in those two areas were found to significantly different in the use of synthetic drugs and impact on their lives.

\section{Discussion}

Different parts of plant, leaf, stem, bark, root/rhizome, flower, fruit, seed, and whole plants are used by them for different ailment, which include gastrointestinal problems (diarrhoea, dysentery, gastritis, abdominal pain, etc.), respiratory tract related problems (cough/cold, sore throat, asthma), cuts and wounds, dermatological problems (burns, swellings and other skin related problems) and other different purposes. The above study concludes people have profound knowledge of medicinal plants and one plant can be used to cure number of diseases without having any side effects. But, they are unknown about the fatalism and hazardous impact of some medicinal plants. The Strong focus should be given for the documentation of uses, traditional knowledge and practices of the medicinal plants and hazardous effect.

Phytochemical analysis of the different medicinal plants revealed the number of chemicals present in it, known to have therapeutic and physiological function. Some of those phytochemicals have more than one function, which has much more scope for further wellorganized research in screening those medicinal plants and evaluating their potential for protection against different types of diseases (Kurmukov, 2013). Alkaloids are important natural products with many pharmacological activities like analgesic, antibacterial, antiasthma and antiarrhythmic (Sayhanet al., 2017), antimalarial and anticancer activities (Wink et al., 1998). Flavonoid possesses several significant properties like antiviral, antibacterial, antifungal, antioxidant, anticancer and antitumor (Xiao et al., 2016), anti-inflammatory (Panche et al., 2016), and antiallergic (Tapas et al.,2008). Glycosides are found to lower blood pressure (Nyarko and Addy, 1990). Tannin containing plant extracts have been used as astringents, diuretics, against diarrhoea, against stomach and duodenal tumors (De Bruyne et al., 1999), antiinflammatory, antiseptic, antioxidant, and haemostatic pharmaceuticals (Dolara et al., 2005). Terpenoids have antimicrobial, antimalarial, anticarcinogenic, antiulcer, and diuretic activity (Dudareva et al., 2009). Saponin regulates blood glucose level and prevents diabetic complications due to their antioxidant activity (El et al., 2017) and also has an inhibitory effect on inflammation (M.J. Just et al., 1998). The allelopathic effect of methanol extract on those medicinal plants may be due to the presence of a single phytochemical compound or may be due to synergetic effect. Those compound interfere with the activities of a respiratory enzyme in seed germination that causes an inhibitory effect of germination (Devkota and Sharma, 2015), or they can alter the action of growth hormone, i.e., Gibberellic acid, which is responsible for the stimulation of germination (Olofsdotter, 2001).

The availability of medical stores, hospitals in Ruru may be the reason for using less medicinal plants and less impact in their daily lives. The literate people are not updated to the different treatment methods and are mainly 
dependent on synthetic drugs rather than medicinal plants. Our study also suggests that the young generation learned about the use of medicinal plants from their family and family members are the most important source of knowledge for the new generations too (similar to Bruschi et al., 2019; Dopico et al., 2008).

\section{Conclusion}

The present study revealed that the study area is rich in various types of valuable medicinal plants and has played a pivotal role in the treatment of several diseases. But, knowledge is gradually decreasing in the young generation. So the concentration for the documentation of this knowledge along with the identification, conservation, and cultivation technique is essential. The phytochemical study showed the presence of some essential chemical constituents in the plants. The literature studied concludes that the presence of those phytoconstituents shows medicinal and physiological properties so that it can be used as a good source for useful drugs. Further study is essential for isolation, purification of those phytochemicals, and analysis of their individual and combined effect using a different technique which could add some value in trade and commerce as these resources have tremendous export potentiality in the Nepalese scenario. Allelopathic effects of the plant extracts were well visible when experimented under the mungbean seeds in the in-vitro condition. These plants could suppress the growth of other plants growing in the same crop field. They indirectly can be used as natural biopesticides that could prevent the infestation of various outcrops. These biopesticides can be less harmful to the environment as compared to synthetic pesticides or other agrochemicals. Other research could be conducted to explore its additional application of such extracts in controlling the insect pest population and disease preventing processes. The knowledge of the medicinal plants is not growing and changing. The youngest generation living in the society could not experience knowledge of different medicinal plants, their impact on health. The perception of people should be focused on the use of medicinal plants. All people, including the young generation, should be aware of the value and crucial contribution of medicinal plants to human societies from ancestors to this period.

\section{Conflicts of interest}

The authors declare that they have no conflicts of interest.

\section{References}

Aasifa G, MBS, Shazia B. 2014. Assessment of allelopathic potential of Cassia sophera L. on seedling growth and physiological basis of weed plants. African Journal of Biotechnology, 13(9), 1037-1046. https://doi.org/ 10.5897/ajb2013.13512

Abhishek G, Apurva J, Joshi VK. 2014. Pharmacognostical Study of Justicia adhatoda. International Journal of Herbal Medicine, 1(6), 1-4.
Acharya R. 2012. Ethnobotanical study of medicinal plants of Resunga hill used by Magar community of Badagaun VDC, Gulmi district, Nepal. Scientific World, 10(10), 54-65. https://doi.org/10.3126/sw.v10i10.6863

Acharya R, Acharya K. 2009. Ethnobotanical Study of Medicinal Plants Used By Tharu Community of Parroha Vdc. Scientific World, 7(7), 80-84.

Ale R, Raskoti BB, Shrestha K. 2009. Ethnobotanical Knowledge of Magar Community in Siluwa VDC, Palpa District, Nepal. Journal of Natural History Museum, 24(August 2018), 5871. https://doi.org/10.3126/jnhm.v24i1.2243

Amb MK, Ahluwalia AS. 2016. Allelopathy: Potential Role to Achieve New Milestones in Rice Cultivation. Rice Science, 23(4), 165-183. https://doi.org/10.1016/j.rsci.2016.06.001

Auwal MS, Saka S, Mairiga IA, Sanda KA, Shuaibu A, Ibrahim A. 2014. Preliminary phytochemical and elemental analysis of aqueous and fractionated pod extracts of Acacia nilotica (Thorn mimosa). Veterinary Research Forum: An International Quarterly Journal, 5(2), 95-100. Retrieved from http://www.ncbi.nlm.nih.gov/pubmed/25568701\%0Ahttp:// www.pubmedcentral.nih.gov/articlerender.fcgi?artid=PMC4 279630

Ayoola GA, Coker HAB, Adesegun SA, Adepoju-bello AA, Obaweya K, Ezennia EC, Atangbayila TO. 2008. Phytochemical Screening and Antioxidant Activities of Some Selected Medicinal Plants Used for Malaria Therapy in Southwestern Nigeria. Tropical Journal of Pharmaceutical Resear, 7(September), 1019-1024.

Badon H, Sharma P, Waheed SM, Singh S. 2016. Investigation of phytochemical composition, evaluation of antioxidant, antibacterial activities, and toxicity study of Emblica officinalis and Terminalia bellirica fruits. Asian Journal of Pharmaceutical and Clinical Research, 9(6), 96-102. https://doi.org/10.22159/ajpcr.2016.v9i6.13731

Bruschi P, Sugni M, Moretti A, Signorini MA, Fico G. 2019. Children's versus adult's knowledge of medicinal plants: an ethnobotanical study in Tremezzina (Como, Lombardy, Italy). Revista Brasileira de Farmacognosia, 29(5), 644-655. https://doi.org/10.1016/j.bjp.2019.04.009

Cowan MM. 1999. Plant products as antimicrobial agents. Clinical Microbiology Reviews, 12(4), 564-582. https://doi.org/10.1128/cmr.12.4.564

Cragg GM, Newman DJ. 2001. Natural product drug discovery in the next millennium. Pharmaceutical Biology, 39(SUPPL.), 8-17. https://doi.org/10.1076/phbi.39.7.8.5868

DB G, RD, SS, AS, Kumar, S. 2014. Grain Legumes in Nepal: Present Scenario and Future Prospects. World Journal of Agricultural Research, 2(5), 216-222. https://doi.org/ 10.12691/wjar-2-5-3

De Bruyne T, Pieters L, Deelstra H, Vlietinck A. 1999. Condensed vegetable tannins: Biodiversity in structure and biological activities. Biochemical Systematics and Ecology, 27(4), 445-459. https://doi.org/10.1016/S0305-1978(98) 00101-X

Devkota A, Sharma S. 2015. Allelopathic Potential of Medicinal Plants: Costus speciosus Koen ex. Retz and Justicia adhatoda Linn. Journal of Natural History Museum, 28(1950), 57-65. https://doi.org/10.3126/jnhm.v28i0.14168

Dolara P, Luceri C, De Filippo C, Femia A, Giovannelli L, Caderni G, Cresci A. 2005. Red wine polyphenols influence carcinogenesis, intestinal microflora, oxidative damage and gene expression profiles of colonic mucosa in F344 rats. Mutation Research - Fundamental and Molecular Mechanisms of Mutagenesis, 591(1-2), 237-246. https://doi.org/10.1016/j.mrfmmm.2005.04.022

Dopico E, San Fabian JL, Garcia-Vazquez E. 2008. Traditional medicine in twenty-first Spain. Human Ecology, 36(1), 125129. https://doi.org/10.1007/s10745-007-9146-1

Dudareva N, Pichersky E, Gershenzon J. 2009. Update on Biochemistry of Plant Volatiles Biochemistry of Plant Volatiles. Plant Physiology, 135(4), 1893-1902. https://doi.org/10.1104/pp.104.049981.1 
El BA, Hussein SA, Alm-Eldeen, AE, Hafez A, Mohamed T. 2017. Diabetes Management Saponins and their potential role in diabetes mellitus. Diabetes Manag, 7(1): 148-158. Retrieved from http://www.openaccessjournals.com/ articles/saponins-and-their-potential-role-in-diabetesmellitus.pdf

Gavit H, Patel N. 2019. Pharmacognostical, phytochemical and physicochemical evaluation of Amaranthus blitum L . leaves from south Gujarat. Journal of Pharmacognosy and Phytochemistry, 8(3), 2148-2155.

Gul R, Jan SU, Faridullah S, Sherani S, Jahan N. 2017. Preliminary Phytochemical Screening, Quantitative Analysis of Alkaloids, and Antioxidant Activity of Crude Plant Extracts from Ephedra intermedia Indigenous to Balochistan. Scientific World Journal, 2017(Figure 1). https://doi.org/ $10.1155 / 2017 / 5873648$

Joseph N, Anjum N, Tripathi YC. 2016. Phytochemical Screening and Evaluation of Polyphenols, Flavonoids and Antioxidant Activity of Prunus cerasoides D . Don Leaves. Journal of Pharmacy Research, 10(7), 502-508.

Kakati D, Gogoi LJ, Sikdar AP. 2016. Comparative study of certain phytochemical properties of Murraya koenigii (L .) Spreng . and Mentha spicata L.: Two aromatic edible medicinal plants of Darrang district, Assam. 5(6), 8234.

Kalimuthu K, Vijayakumar S, Senthilkumar R. 2010. Antimicrobial activity of the biodiesel plant, Jatropha curcas L. International Journal of Pharma and Bio Sciences, 1(3), 1-5.

Krishnaveni M, Hariharan D. 2017. Phytochemical Analysis of Mucuna Pruriens and Hyoscyamus Niger Seeds. 7(2), 6-13.

Kumar M, Dandapat S, Sinha MP. 2015. Phytochemical Analysis and Growth Inhibitory Impact of Swertia chirayita Aqueous Leaf Extract Against Some Human Pathogens. World Journal of Zoology, 10(3), 188-190. https://doi.org/10.5829/ idosi.wjz.2015.10.3.94138

Kurmukov AG. 2013. Phytochemistry of medicinal plants. In Medicinal Plants of Central Asia: Uzbekistan and Kyrgyzstan (Vol. 1, pp. 13-14). https://doi.org/10.1007/978-1-46143912-7_4

Lehoczky E, Nelima MO, Szabó R, Szalai A, Nagy P. 2011. Allelopathic effect of Bromus spp. and Lolium spp. shoot extracts on some crops. Communications in Agricultural and Applied Biological Sciences, 76(3), 537-544.

Lellau TF, Liebezeit G. 2001. Alkaloids, Saponins and Phenolic compounds in salt marsh plants from the lower Saxonian Wadden Sea. Senckenbergiana Maritima, 31(1), 1-9. https://doi.org/10.1007/BF03042831

Lokman H, Hossaim MA, Kumar SK, Arif H, Anisur R. 2013. Phytochemical Screening and the Evaluation of the Antioxidant, Total Phonelic Content and Analgesic Properties of the Plant Pandanus foetidus (Family: Pandanaceae). International Research Journal of Pharmacy, 4(2), 170-172. Retrieved from www.irjponline.com

M Kaur, SS, SG, MA. 2018. Study of Antibacterial Activity of Chenopodium album Leaves Extract. International Journal of Pharmacognosy and Phytochemical Research, 10(01), 1-4. https://doi.org/10.25258/phyto.v10i01.11923

MJ Just, MG Recsio, RM Gner, MJ Cuellar, S Marez, AR, Bilia JR. 1998. Anti-inflammatory activity of unusual lupane saponins from Buleurum fruiticescens. , 1998; 64(5):404407. [26]. Planta Medica, (9), 404-407.

M Krishnaveni, PGA, KRA. 2017. Comparative Phytochemical Analysis of Alpinia officinarum Rhizome and Terminalia chebula Fruit. International Journal of Pharmacy and Biological Sciences, 7(1), 32-39. https://doi.org/10.21276/ ijpbs.2017.7.1.5

Malathi R, KD, CS. 2018. Preliminary phytochemical analysis of Justicia adhatoda leaves extract using different solvents. Int J Pharm Drug Anal, 6(2), 186-190.
Mamta S, Jyoti S. 2012. Phytochemical Screening of Acorus calamus and Lantana Camara. International Reaseach Journal of Pharmacy, 3(8), 324-326. https://doi.org/10.3109/ 00016358709096356

Marka R, Talari S, Penchala S, Rudroju S, Swamy Nanna R. 2013. Preliminary phytochemical analysis of leaf, stem, root and seed extracts of Arachis hypogaea L. International Journal of Pharmaceutical Sciences Review and Research, 20(1), 134-139.

Mehta DK, Das R, Bhandari A. 2013. Phytochemical screening and HPLC analysis of flavonoid and anthraquinone glycoside in Zanthoxylum armatum fruit. International Journal of Pharmacy and Pharmaceutical Sciences, 5(SUPPL 3), 190-193.

Narasimhan R. 2014. Phytochemical Screening and Evaluation of Protein content in the Seed extracts of Cucurbita maxima. 5(7), 3637-3642.

Ncube NS, Afolayan AJ, Okoh AI. 2008. Assessment techniques of antimicrobial properties of natural compounds of plant origin: Current methods and future trends. African Journal of Biotechnology, 7(12), 1797-1806. https://doi.org/10.5897/ AJB07.613

Nehal N, Mann S, Gupta RK. 2016. Nutritional and phytochemical evaluation of A. lividus L. syn. Amaranthus blitum subsp. oleraceus (L.) Costea leaves. Indian Journal of Traditional Knowledge, 15(4), 669-674.

Nyarko AA, Addy ME. 1990. Effect of aqueous extract of Adenia cissampeloides on blood pressure and serum analytes of hypertensive patients. Phytotherapy Research, 4(1), 25-28. https://doi.org/10.1002/ptr.2650040107

Olofsdotter M. 2001. Rice - A step toward use of allelopathy. Agronomy Journal, 93(1), 3-8. https://doi.org/10.2134/ agronj2001.9313

Panchal P, Parvez N. 2019. Phytochemical analysis of medicinal herb (Ocimum sanctum). International Journal of Nanomaterials, Nanotechnology and Nanomedicine, 5(2), 008-011. https://doi.org/10.17352/2455-3492.000029

Panche AN, Diwan AD, Chandra SR. 2016. Flavonoids: An overview. Journal of Nutritional Science, 5. https://doi.org/10.1017/jns.2016.41

Poudyali B, Singh B. 2019. Potential antibacterial and antioxidant properties of aqueous, ethanol and methanol extract of Tectaria macrodonata C. chr. International Journal of Pharmaceutical Sciences and Research, 10(8), 3785-3794. https://doi.org/.1037//0033-2909.I26.1.78

Saini R, Kumar D, Mittal A. 2019. Antimicrobial and phytochemical potential of Chenopodium album linn. International Journal of Scientific and Technology Research, $8(7), 877-880$.

Sayhan H, Beyaz SG, Çeliktaş A. 2017. The Local Anesthetic and Pain Relief Activity of Alkaloids. In Alkaloids - Alternatives in Synthesis, Modification and Application. https://doi.org/ 10.5772/intechopen.69847

Sharma S, Devkota A. 2015. Allelopathic Potential and Phytochemical Screening of Four Medicinal Plants of Nepal. Scientific World, 12(12), 56-61. https://doi.org/10.3126/ sw.v12i12.13598

Sharma UR, Malla KJ, Uprety, RK. 2004. Banko janakari : a journal of forestry information for nepal. Banko Janakari, Vol. 14, pp. 3-11. Retrieved from https://www.nepjol.info/ index.php/BANKO/article/view/17044/13851

Shrestha P, Adhikari S, Lamichhane B, Shrestha BG. 2015. Phytochemical Screening of the Medicinal Plants of Nepal. Journal of Environmental Science, Toxicology and Food Technology, 1(6), 11-17.

Shrestha R, Neupane R, Adhikari N. 2011. Status and Future Prospects of Pulses in Nepal 1. Regional Workshop on Pulse Production, (October), 1-30. Retrieved from http://www.nepalpolicynet.com/images/documents/agricultu re/research/Status and Future Prospects of Pulses in Nepal_NARC.pdf 
Tapas A, Sakarkar D, Kakde R. 2008. Flavonoids as Nutraceuticals: A Review. Tropical Journal of Pharmaceutical Research, 7(3), 1089-1099. https://doi.org/ 10.4314/tjpr.v7i3.14693

Thakur S, Sidhu MC. 2014. Phytochemical screening of some traditional medicinal plants. Research Journal of Pharmaceutical, Biological and Chemical Sciences, 5(4), 1088-1097.

Tiwari A, Uprety Y, Rana SK. 2019. Plant endemism in the Nepal Himalayas and phytogeographical implications. Plant Diversity, 41(3), 174-182. https://doi.org/10.1016/ j.pld.2019.04.004

Vaghasiya Y, Dave R, Chanda S. 2011. Phytochemical analysis of some medicinal plants from western region of India. Research Journal of Medicinal Plant, 5(5), 567-576. https://doi.org/10.3923/rjmp.2011.567.576
Vemuri PK, Dronavalli L, Nayakudugari P, Kunta A, Challagulla R. 2019. Phytochemical analysis and biochemical characterization of Terminalia chebula extracts for its medicinal use. Biomedical and Pharmacology Journal, 12(3), 1525-1529. https://doi.org/10.13005/bpj/1783

Weston LA. 1996. Utilization of allelopathy for weed management in agroecosystems. Agronomy Journal, 88(6), 860-866. https://doi.org/10.2134/agronj1996.00021962003600060004x

Wink M, Schmeller T, Latz-Brüning B. 1998. Modes of action of allelochemical alkaloids: Interaction with neuroreceptors, DNA, and other molecular targets. Journal of Chemical Ecology, 24(11), 1881-1937. https://doi.org/10.1023/A: 1022315802264

Xiao J, Capanoglu E, Jassbi AR, Miron A. 2016. Advance on the Flavonoid C-glycosides and Health Benefits. Critical Reviews in Food Science and Nutrition, 56(November 2017), S29-S45. https://doi.org/10.1080/10408398.2015.1067595 